Araujo, H.R.; Ávila, G.C.; Paula, V.C.; Souza, D.E. Monitoramento da visitação do Parque Estadual do Biribiri e suas contribuições para o planejamento e gestão do uso público da Unidade de Conservação. Anais do VIII Congresso Nacional de Ecoturismo e do IV Encontro Interdisciplinar de Ecoturismo em Unidades de Conservação. Revista Brasileira de Ecoturismo, São Paulo, v.4, n.4, 2011, p. 553.

\title{
MONITORAMENTO DA VISITAÇÃO DO PARQUE ESTADUAL DO BIRIBIRI E SUAS CONTRIBUIÇÕES PARA O PLANEJAMENTO E GESTÃO DO USO PÚBLICO DA UNIDADE DE CONSERVAÇÃO
}

\author{
Hugo Rodrigues Araujo*, Gabriel Carvalho de Ávila*, Viviane Cristina de Paula*, \\ Daniella Eloi de Souza**
}

\author{
*Instituto Biotrópicos, **Universidade Federal dos Vales do Jequitinhonha e Mucuri \\ E-mails: hugo@biotropicos.org.br, gabriel.avila@meioambiente.mg.gov.br, \\ viviane.paula@meioambiente.mg.gov.br, daniella_eloi@msn.com
}

O Parque Estadual do Biribiri - PEBI criado pelo Decreto Estadual de №. 39.909, de 22 de setembro de 1998, está localizado no município de Diamantina - MG e é administrado pelo Instituto Estadual de Florestas de Minas Gerais. De acordo com o Sistema Nacional de Unidades de Conservação, os parques têm a finalidade de proteger a biodiversidade local, promover e auxiliar estudos e pesquisas científicas, e criar alternativas do uso sustentável dos recursos naturais, interpretação ambiental, através da prática de recreação e lazer, como o ecoturismo. A criação do PEBI se justifica pelo fato de sua área apresentar várias espécies da fauna e flora ameaçadas de extinção, além de possuir inúmeros atrativos turísticos e importantes sítios arqueológicos. Apesar de não estar oficialmente aberto à visitação, o PEBI é um dos Parques Estaduais mais visitados de Minas Gerais. Em média, mais de 40.000 visitantes vão ao PEBI anualmente. $\mathrm{O}$ vigente trabalho visa expor os dados gerados pelo monitoramento da visitação do PEBI e detalhar suas implicações para o planejamento e gestão da unidade. A falta de estruturação do Parque e os impactos ambientais inerentes da visitação pública justificaram o início de ações de quantificação e qualificação dos seus visitantes. Este trabalho iniciou-se no ano de 2008 e é executado pela equipe do PEBI e seus colaboradores, no acesso aos principais atrativos do Parque, todos os dias do ano, das 08 às 18 horas. Os visitantes são abordados recebendo as normas do $\mathrm{PEBI}$, momento este em que são colhidos os dados que são posteriormente tabulados e divulgados. Identificou-se que o mês com maior visitação é fevereiro seguido por janeiro com médias de 8908 e 4284 visitantes respectivamente. O mês com menor visitação foi junho com média de 1300 visitantes. Dos visitantes $47 \%$ são originários de Diamantina, $20 \%$ são de Belo Horizonte e $8 \%$ vêm de outros estados. Identificou-se que somente $6 \%$ dos visitantes não se utilizam de meios de transporte motorizados, sendo que $3 \%$ são ciclistas e $3 \%$ adentram ao Parque a pé. Quanto às atividades pretendidas dentro do PEBI as de balneários foram citadas por $40 \%$ dos entrevistados seguida pela busca por paisagens com $16 \%$, e pelas caminhadas e pelos esportes de aventura ambos citados por $11 \%$ dos entrevistados. Os dados levantados têm embasado o planejamento do PEBI, subsidiando ações emergenciais que visam melhorias no uso público, antes mesmo da sua abertura oficial. Além disso, estes dados permitem a programação das ações contingenciais evitando esforços excessivos ou subestimados da equipe. A pesquisa indicou quais atividades de ecoturismo devem ser prioritariamente desenvolvidas dentro do PEBI. O contato com os visitantes possibilitou ainda a difusão de normas de conduta dentro da unidade, o que têm contribuído para minimizar impactos e multiplicar as informações referentes á unidade de conservação na comunidade.

Palavras-chaves: Unidade de Conservação; Monitoramento; Planejamento. 